DIW BERLIN

Discussion

Papers
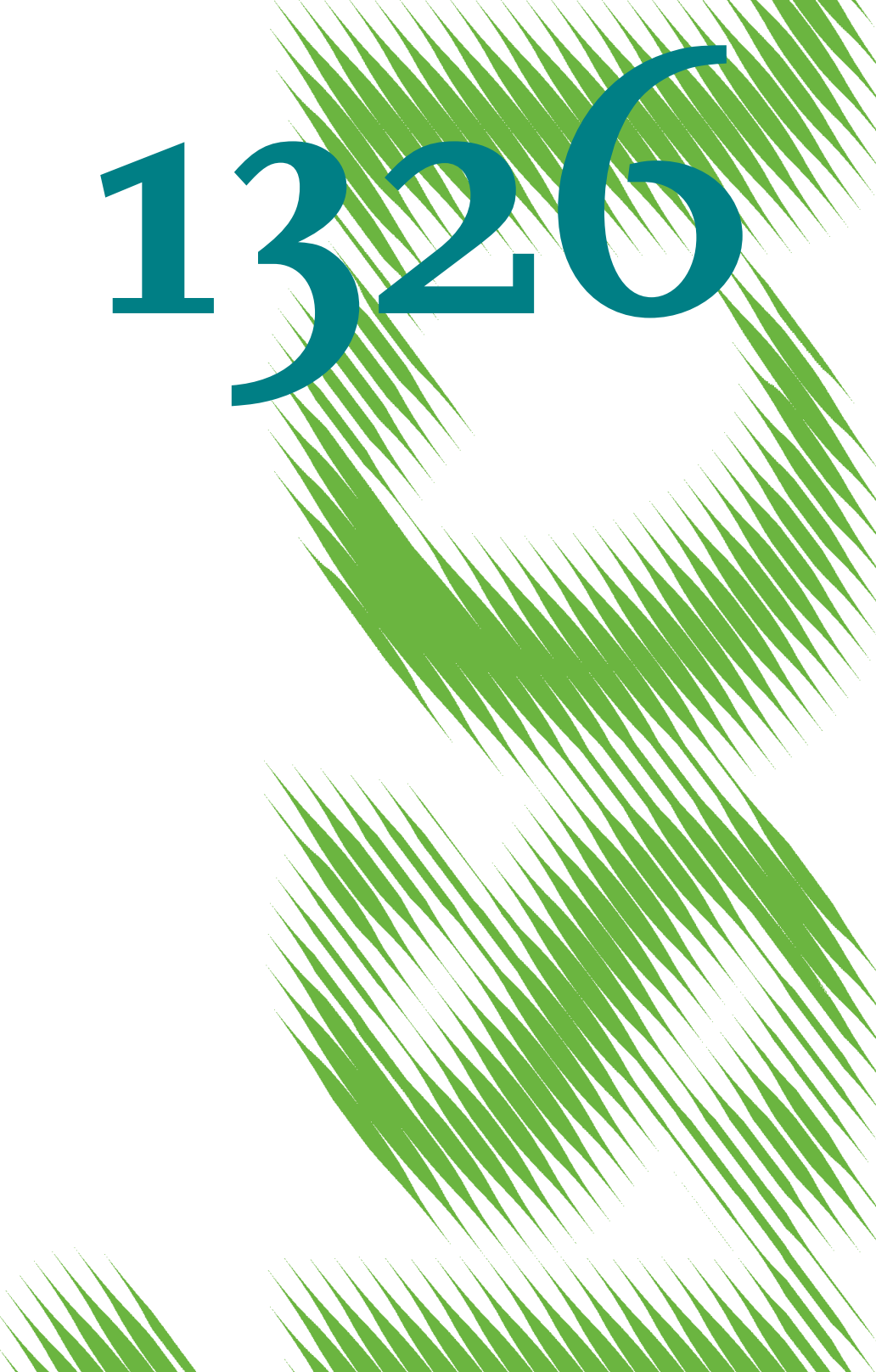

110 1

Skills in the Marketplace

Individual Characteristics and Bargaining Ability in a Field-Based Experiment 
Opinions expressed in this paper are those of the author(s) and do not necessarily reflect views of the institute.

IMPRESSUM

(C) DIW Berlin, 2013

DIW Berlin

German Institute for Economic Research

Mohrenstr. 58

10117 Berlin

Tel. $+49(30) 89789-0$

Fax +49 (30) $89789-200$

http://www.diw.de

ISSN print edition $1433-0210$

ISSN electronic edition 1619-4535

Papers can be downloaded free of charge from the DIW Berlin website:

http://www.diw.de/discussionpapers

Discussion Papers of DIW Berlin are indexed in RePEc and SSRN:

http://ideas.repec.org/s/diw/diwwpp.html

http://www.ssrn.com/link/DIW-Berlin-German-Inst-Econ-Res.html 


\title{
Skills in the Marketplace: Individual Characteristics and Bargaining Ability in a Field-Based Experiment ${ }^{1}$
}

\author{
Nathan Fiala ${ }^{2}$
}

August 2013

\begin{abstract}
Classic economic theory predicts that markets will clear, leaving little or no gains from trade left on the table. Laboratory experiments have largely confirmed this, though the results of recent field experiments have been mixed, with some artefactual markets in developing countries performing relatively inefficiently. I create a realistic multi-round trading market in Uganda with market-experienced individuals to explore the efficiency of trading and test what individual traits predict market efficiency and bargaining success using a rich dataset on individual characteristics. In early rounds, market efficiency is low. By the final round, efficiency rates are closer to theory. I find that individual characteristics of the buyers and sellers strongly predict the level of efficiency within the individual rounds. Individual characteristics are also important for individual success and divide along bargaining power: for buyers, who by design have high market power, wealth and patience are positively and significantly correlated with rents; for sellers with low market power, education, anti-social behavior and aggression are positively and significantly associated with rents. The results of the bargaining game also correlate with wealth levels two years after the experiment, suggesting that market prowess predicts lifetime outcomes. The results add importance to the role of individual characteristics for individual and social efficiency outcomes.
\end{abstract}

Keywords: Market interaction; market efficiency; developing markets; individual characteristics

\footnotetext{
${ }^{1}$ Acknowledgements: Funding for games data collection was provided by the author. Individual characteristics data come from an experiment as described in Blattman, Fiala, and Martinez (2013). I would like to thank IZA, who hosted me during the drafting of this paper, as well as Alex Segura and Judith Achan for their data collection assistance. Special thanks goes to David Fiocco, who helped design the fieldwork and kept the project motivated.

${ }^{2}$ German Institute for Economic Research, DIW Berlin, Mohrenstraße 58, 10117 Berlin, Germany, nfiala@diw.de.
} 


\section{Introduction}

The prediction that markets in equilibrium will clear, leaving behind little or no gains from trade, is oft cited in classical economic theory. Financial and trading markets in developed countries have largely confirmed this prediction (Fama 1970), along with a number of laboratory games, starting with Smith (1962). In a field experiment with memorabilia traders, List (2004) found efficiency rates as high as $97 \%$ in some rounds of trading.

Evidence on market efficiency in developing countries is more mixed. Financial markets are often incomplete, but those that exist perform relatively well (Magnusson and Wydick 2002). Among small-scale traders, the results are less promising. Bulte, et al. (2013) find efficiency rates below 90\% among inexperienced trading communities in Sierra Leone. Through a novel experimental design, they find that varying interaction mechanisms can increase this rate, though there are still significant inefficiencies. Their results suggest that expanding market growth will help push out inefficiencies; however, there is still good reason to be worried about the lack of efficient outcomes and the reasons for this.

Existing laboratory and field bargaining games have focused their interests on the overall efficiency of markets but have paid little attention to who is participating in the market. Within most any market, some individuals will likely do better than others at bargaining, based on a range of personal abilities and characteristics. If these characteristics affect not just individual success, but also larger market efficiency, the wrong mix of characteristics could lead to inefficient outcomes. In this paper, I describe the results of an experiment in Uganda that merges individual outcome data from a bargaining experiment with detailed individual preferences, personality, and skills-based information. I create a private auction, multi-round trading market that well reflects the actual market conditions that people in Uganda regularly face. I use the results to explore the efficiency of trading and test what individual traits predict market efficiency and individual bargaining success.

In early rounds of trading, I find low efficiency results, similar to Bulte, et al. (2013). By the final rounds, efficiency rates are higher and close to theory. Rents, however, are not equally distrib- 
uted among participants. Consistent with a Rubinstein infinite round sequential bargaining game with time discounting where buyers make the first offer, buyers perform significantly better than sellers.

I also find that certain individual characteristics are important for success, both of the overall market and for individuals. The average age, human capital and wealth of participants is positively associated with market efficiency, while average patience, pro-social, anti-social and aggressive characteristics are negatively associated with efficiency.

The results for individual success divide along buyers and sellers, likely in part due to the differential market power that places a significant amount of stress on the sellers, who need to work even harder to extract rents. Buyers who are wealthier and more patient perform better in the game. For sellers, higher levels of education, anti-social behavior and aggression are associated with better outcomes.

The results of the bargaining game also positively predict individual income levels two years after the experiment, which suggests that the skills necessary for market success correlate positively with real world economic life outcomes.

The results of this experiment suggest that market buyers and sellers in a developing country are leaving some rents behind, though not as large as one might expect. These amounts are also predictable based on individual characteristics. The results also suggest that a range of skills, divided along perceived market power, matter for individual market outcomes and behavior. Marketplace dynamics in developed countries are becoming less important over time ${ }^{3}$, but the importance for developing countries is very significant. The research discussed here helps to better understand what makes for an efficient market and a successful negotiator in the market.

${ }^{3}$ See Einav , et al. (2013) for a discussion of the declining role of auctions in online trading. 
This paper proceeds as follows. The next section explores some of the literature on personal characteristics and economic outcomes. Section 3 describes the setting and experimental design. In section 4, I discuss the efficiency rates achieved in the games. In section 5, I detail the individual characteristic variables. Section 6 presents an analysis of what individual characteristics matter for market efficiency. In section 7, I explore individual outcomes, starting first with the predictors of who trades, then looking at the individual characteristics that correlate with individual success in the games. In section 8 , I test how the results of the games predict future income. Section 9 concludes.

\section{Evidence on Personal Traits and Success}

There is a growing literature on how individual characteristics and skills correlate with economic outcomes. DellaVigna (2009) summarizes recent research into how individuals deviate from standard economic models, including the role of social preferences, limited attention and persuasion in market outcomes. He then discusses how experience can limit the impacts of these characteristics. Heckman, Stixrud and Urzua (2006) present evidence that cognitive and noncognitive skills predict a number of economic outcomes, including employment, wages and occupational choice.

There is also work on what characteristics make a successful entrepreneur, which is of interest as these individuals often have to interact in the marketplace. Iyer and Schoar (2008) conduct a market experiment by sending buyers to negotiate with sellers and look at final price agreements. The authors then test if a buyer being from a different community than a seller determines the outcome. They find that prices are lower for community matches.

There is also some evidence on individual business owner characteristics for business outcomes. Bates (1990) follows small business and finds education is the major determinant of business survival and capital structure. Djankov, et al (2008) look at the determinants of being an entrepreneur. Family characteristics are the best predictor of becoming an entrepreneur in 
Brazil. Acharya, Rajan, and Schoar (2007) explore the psychology of entrepreneur success by correlating different characteristics and economic returns. They find that self-efficacy, achievement motivation, age, and prior borrowing experience are all correlated with success. Bloom and Van Reenen (2007) collect data on management practices (and ability). They find a large heterogeneity of business quality as a lot of businesses are poorly managed. More competition decreases bad management; businesses passed down in the family are generally the worst managed. Finally, Simeon Djankov, Yingyi Qian, Gérard Roland, and Ekaterina Zhuravskaya (2008) test if attitude toward risk, I.Q., self-confidence, family background and social networks predict business outcomes. They find that family characteristics have an influence on whether someone becomes an entrepreneur, though business outcomes are best predicted by intelligence and family education. They do not find that entrepreneurs are more selfconfident.

However, the evidence on personal characteristics for general market interaction does not appear to be present. To the author's knowledge, this paper presents the first evidence of individual market success in normal market interactions.

\section{Experimental Design}

This research uses one of the oldest experimental games in economics, the double-auction game, in a novel way. Researchers have historically used this auction to study how and if markets reach equilibrium. For our purposes, it is extended to also measure individual ability within a marketplace.

The literature on using such games to measure individual ability is small and confined to classroom settings with single auctions. For instance, Kagel and Richard (1998) look at the prevalence of the winner's curse in those with a lot of experience in markets and those with little experience, while List (2002) looks at the differential returns and equilibrium of pairing experienced buyers and sellers with inexperienced buyers and sellers. There is also a literature look- 
ing at the differences in competitive behavior across genders in market settings (Gneezy, Niederle and Rustichini 2003 and Ham and Kagel 2006) and behavior in a sealed auction (Cheny, Katušcákz and Ozdenoren 2005). Researchers have also studied the role of risk aversion and discounting with cognitive ability (Benjamin, Brown and Shapiro 2006). Finally, Garvin and Kagel (1994) and Casari, Ham, and Kagel (2006) look at correlations between the winner's curse and gender and ability, as measured by SAT scores.

Only in the last two studies are individual outcomes in a market game correlated with demographics. While the literature acknowledges heterogeneity of outcomes across individuals and the ability to collect direct data on individual abilities, no study has yet used this information to understand outcomes in the real world, either in a laboratory of field setting.

The experiments described in this paper were conducted in the Langi region of northern Uganda. All of the participants come from the same Lango ethnic group. Participants were invited from a pool of individuals taking part in a randomized evaluation of a cash-grant project, described in Blattman, Fiala, and Martinez (2013). The games required a certain number of participants to be present, but the number who showed up out of the invited pool did not always reach this amount. When there were too few invited participants, people were selected from the local community. In total, $78.5 \%$ of the sample population is from the evaluation sample. In general, the evaluation sample does not perform differently than the community sample.

In the game, individuals were randomly assigned as either sellers or buyers and given cards with either their costs or values, respectively. Those selected to be buyers or sellers kept their positions for the remainder of the game.

Participants played the game as a private market. Individuals were allowed to freely roam around a large room and negotiate prices with opposite types. When a price was reached, participants approached an enumerator and quietly informed them of the price. The price was then recorded along with the value and costs of the two players. All information was kept private. Individuals then left with actual payouts of their profit or surplus value. 
The values for buyers started at 1,700 USH (\$0.85) and proceeded by amounts of 300 USH $(\$ 0.15)$ until they reached the maximum value of 4,400 USH $(\$ 2.20)$. For sellers, the lowest cost started at 1300 USH and increased by 300 USH until they reached 4,000 USH. The most socially efficient outcome is presented in Figure 1, where equilibrium price is between 2,700 USH and 2,800 USH and equilibrium quantity traded between 5 and 6 . The maximum amount of rent per round is 9,600 USH in total ${ }^{4}$.

Participants were told that the game was meant to mimic the marketplaces found in large and small towns across Uganda. Buyers were to approach sellers and offer prices, with all information kept private to facilitate optimal bargaining. Sellers were also encouraged to look for buyers. A time limit was imposed of 5 minutes per round, which was enough time for buyers and sellers to negotiate with a number of people.

The games were run in early 2010. A local research team including a manager and two assistants collected the data. All three spoke the local language, Luo, which was the main language of the games. The researcher and the researcher assistant trained the team, who then issued clear instructions to the team on how to explain the games to participants, when and how to answer questions, and how to record information. The full protocols are included in the Appendix.

A total of 10 game sessions were run with 20 participants in each session. Ten individuals were selected as buyers and 10 were selected as sellers. The researcher predetermined all costs and values distributed. The game locations were in preselected areas that invited participants could easily access.

The setup resembles an infinite round Rubinstein sequential bargaining game with discounting where players bargain over some item of value 1 (Rubinstein 1982). In round 1, Player 1 (the buyer) moves first and offers a split of the item, $s_{1}$. Player 2 (seller) can then accept or reject the

\footnotetext{
${ }^{4}$ The normal daily wage in northern Uganda at the time was about 6,000 USH (\$3.00).
} 
offer. If she accepts, the buyer receives $s_{1}$ and the seller receives $1-s_{1}$. If she rejects, the players go to the second round and the value of the item decreases by amount $\delta$. The seller then gets to propose a split $s_{2}$, while the buyer can then accept or reject. This is then continued for an infinite number of rounds. Solving for the Nash equilibrium, the buyer will suggest a split of $s_{1}=$ $1 /(1+\delta)$ in the first round and the seller accepts, receiving $1-s_{1}=\delta /(1+\delta)$. The buyer thus receives more as $\delta$ decreases, with $s_{1}=1 / 2$ as $\delta \rightarrow 1$. Critically, the payoff for the buyer always dominates the seller. Buyers thus have greater market power, while sellers have less power.

This model assumes that all participants have the same bargaining abilities. In the real world, it is unlikely that this would be the case. Some people in a market will probably be better than others at obtaining rents based on individual ability.

Assume that the pair of buyers and sellers have individual characteristics functions $f_{b}(\cdot)$ and $f_{s}(\cdot)$ that determine how well they are able to convince the other participant in the division of the item. If $f_{b}=f_{s}$, and both can solve the game, then the resulting split will be as predicted. If instead $f_{b}>f_{s}$, then the buyer can obtain an even greater share of the item. If $f_{b} \ll<f_{s}$, it is possible that the seller could overcome his bargaining power disadvantage and realize a greater share than the buyer.

Given that buyers and sellers have differential bargaining power, it is likely that these characteristic functions will be composed of different elements. It is reasonable to ask then what characteristics are likely in $f_{s}$ and $f_{b}$ ? There is not much evidence on what these characteristics would be, but one might expect both buyers and sellers to need experience. Women are often seen as having worse outcomes in labor market negotiations, but this difference has not held in market experiments. Sellers, with a lower bargaining power, will likely need to act quickly to obtain better results. Buyers can instead afford to take their time.

The composition of this characteristic function could be important for determining who will succeed and who will fail at bargaining. It can also be instructive to understand what characteristics are missing from people in markets that are not acting efficiently. This paper thus looks at seven types of individual characteristics: intelligence, wealth, risk and time preferences, pro- 
and anti-social behavior, and aggression. I test the relative importance of each, assuming they enter the characteristic function linearly.

\section{Market Efficiency}

The summary statistics for the games are presented in Table 1. The average price across the rounds is $2,700 \mathrm{USH}$, which is $95 \%$ of the predicted amount of $2,850 \mathrm{USH}$. Across all of the rounds, the prices average between $90 \%$ and $98 \%$ of the predicted level, with very little change across the rounds. Individual price levels within each session, though, were quite varied and reflect a high heterogeneity in price agreement.

Individual average rents are likewise consistent around 700 USH. Twenty-two trades (less than $2 \%$ of all trades) were made with negative rents. This is likely due to some people in early stages misunderstanding the rules. In the later stages, there are no negative trades. There is a high level of heterogeneity in rent returns, with some people performing exceptionally well. As predicted, there is a large difference in returns between buyers and sellers. Buyers averaged 293 USH more rents each round than sellers, about $40 \%$ of the average rent. This suggests buyers had a large market power compared to sellers.

Efficiency rates are calculated as the percent of total possible rents available that were obtained by the entire group in each round. In the early rounds, the rates are well below $90 \%$, which is consistent with the results of Bulte, et al. (2013) in Sierra Leone. As can be seen in Figure 2, these rates improve over time. By the last round, efficiency has increased to $93 \%$. In 11 of the 100 total rounds played, efficiency was at $99 \%$ or greater.

The average efficiency rate includes a small number of very poor performing game sessions. Dropping the single worst performing session in the last period increases efficiency to $96 \%$. Figure 2 also presents the results of different dropping rules, including dropping the lowest performing session each round, as well as dropping session 3, which, on average, performed the 
worst of all sessions. Dropping does not significantly change the interpretation of the results, though it does increase the efficiency rate by a few percent each round.

Maximizing efficiency comes from an optimal matching of buyers and sellers. By design, market equilibrium in the game means four buyers and four sellers would not trade. This did not happen in 31 of the 100 total rounds played. Even in the last round, there are fewer than predicted no-trades in three of the sessions.

The results on market efficiency are positive overall, though there is clearly room for improvement before full efficiency is reached.

\section{Measures of Individual Characteristics}

In this section, I discuss the individual characteristics collected and how they correlate with individual performance in the games. Individual characteristics were collected as part of a larger evaluation of a cash transfer program designed by the Government of Uganda and World Bank. The variables were collected either in 2008 or 2010, which coincided with the games data collection. Data collected includes a wide range of economic, social and psychological indicators, as discussed in Blattman, Fiala, and Martinez (2013).

Table 2 presents the summary statistics for individual characteristics used in the analysis presented here. Individuals are relatively young (25 years of age on average), with $29 \%$ being female. Compared to other young people in northern Uganda, the participants are slightly better off in terms of literacy and assets. They are still very poor by most measures and fall below the Government of Uganda's poverty threshold.

All indices are constructed by normalizing each component piece to mean of 0 and variance of 1 , summing the components, and then normalizing the sum. The variables and their construction are as follows. 


\subsection{Human Capital}

The human capital index is composed of measures of individual intelligence and education. It includes years of education and whether the person felt she could read and/or write in her native language or English. It also includes whether the person ever received vocational training, which is a common supplemental education after finishing public schooling. To test for intelligence, researchers administers a number recall game to individuals to test how well they remember a string of numbers read by an enumerator, as well as a numeracy test, which asked simple math questions.

\subsection{Wealth}

The wealth index includes a principle component analysis index of assets, which is constructed from a list of over 50 common household assets. Assets were asked one-by-one to participants to ensure there was no issue with recall of ownership. The index also includes current cash savings, which are not common in this context. Finally, it includes cash earned in the last month from all economic activities. Again, to avoid recall errors, the enumerator provided a list of 25 common activities with the respondent noting whether they engaged in that activity in the last four weeks and how much income they received from it.

\subsection{Risk}

The risk index is constructed from a set of localized questions to test daily risk preferences. A common type of question was as follows: 
Suppose you have a severe pain in your leg. You have the choice between two options.

Option A: You can get some medicine that will reduce the pain but will not cure you.

Option B: You can get surgery that will cure you; however, there is a small risk of death. Which option would you choose?

Participants then chose which option they preferred. These questions were constructed to mimic real-life risk situations people faced.

Participants were also asked the following at the end of the questionnaire:

You have a choice between the following two options. Option A: You can receive 2000 USH for sure.

Option B: We play Labyeka. If you win, you get 3000 USH. If you lose, you get 1000 USH. Which option do you choose?

Labyeka is a well-known local game of chance. After they made their decision, individuals then played the game and were paid based upon their choices and the outcomes.

\subsection{Patience}

Patience was also determined through a questionnaire using a set of localized questions. An example question to test patience is as follows:

Suppose you are sick. The illness is not life-long, but it will last for a few months. You have the choice between two options.

Option A: You can get some medicine today, which will make you feel somewhat better.

Option B: You can wait a week until a better medicine is available that will make you feel entirely good again. You can only choose one medicine. Which option do you choose? 
It was decided not to include incentivized questions that include a time lag as there was no credible way to pay participants after the questionnaire was completed.

\subsection{Pro- and Anti-Social}

The pro-(anti-)social variables are constructed from a set of localized questions designed to test positive (negative) interactions with other people and the community. The pro-social questions addressed how many groups the individual participated in with other community members, such as religious and sports groups. It also tries to measure the quality of interactions with community members, i.e. whether community members were helpful to them, and vice versa. Anti-social questions focused on problems interacting in the community. For example, individuals were asked "Do you keep to yourself when you are worried?" and rated this as often, sometimes, rarely, and never.

\subsection{Aggression}

The aggression index is a construct of self-reported actual fights and arguments with family, neighbors and police. These communities are not prone to high levels of fighting or aggression; nonetheless, there were some issues reported. While it is possible that this variable is the most prone to being misreported by respondents, the individuals were generally open to discussing such incidents.

\section{When Are Markets Efficient?}

Participants played a total of 100 rounds over 10 sessions. As discussed in section 4, efficiency rates varied per round and by sessions. Figure 3 presents the incidence of efficiency rates. The majority are quite good, though there is some important variation. In this section, I look at what 
aggregate average individual characteristics correlate with the realized efficiency rates. To do so, I estimate the following model:

$$
E_{r}=\gamma X_{s}+\mu r+\varepsilon_{r}
$$

Where $r$ is the round, $s$ is the session, $E$ is the efficiency rate in round $r, X$ is the full set of individual characteristics, averaged per session, and $\varepsilon$ is the error term.

I present the results of estimating Equation 1 using OLS in Table 3. Column 1 presents the results for the entire sample. Columns 2 to 4 explore different truncations of the data, including trimming either $5 \%$ of the top or bottom performing rounds or trimming both. Mean age is positive and significant across all of the samples, as is mean human capital, whose coefficient is large. Percent female and average wealth is positive but not significant across most of the specifications. Risk aversion is negatively associated, but is not significant for any sample. Mean patience, pro-social, anti-social and aggression indices are all large, negative and very significant.

The results suggest that the characteristics of market participants are very important for the efficiency of the market. Experience and intelligence are predictive of efficient markets. Patience is a bad characteristic for market efficiency, as is anti-social and aggressive behavior. I also find a negative role for pro-social outcomes. This could be interpreted as similar to the results found by Bulte, et al. (2013), who show that increasing market anonymity increases efficiency.

The results are also positive for the rounds variable. Efficiency rates increased by $0.6 \%$ per round for the full sample, suggesting there was learning over time. However, this is no longer significant when trimming the bottom performing rounds, suggesting that learning was important for the lowest performing groups. 


\section{Individual Market Outcomes}

As described earlier, individuals were selected to be either buyers or sellers and assigned specific ID numbers, which, unknown to them, corresponded to what value (buyers) or cost (sellers) they would be given throughout the games. These values (costs) were staggered such that each person received each value (cost) once throughout the 10 rounds. As the ID numbers were distributed randomly, it is unlikely there is selection among the timing of the received values (costs). As a test of this possible selection, Table 4 presents a test of balance across a range of individual indicators. Individual characteristics are not related to whether a person was selected as a buyer or seller, suggesting there was little or no selection into the individual roles.

\subsection{Who Trades?}

To test who engages in trade, I estimate the following model on those that trade and those that do not:

$$
\mathrm{T}_{\mathrm{ir}}=\alpha \mathrm{V}_{\mathrm{ir}}+\beta \mathrm{S}_{\mathrm{ir}}+\delta \mathrm{R}_{\mathrm{ir}}+\gamma \mathrm{X}_{\mathrm{i}}+\varepsilon_{\mathrm{ir}}
$$

Where $i$ is the individual, $r$ is the round, $T$ is a dummy for whether the individual traded, $V$ is a dummy for whether the value (cost) they received is too low (high) and so should not be traded in equilibrium, $S$ is a matrix of dummies for the session an individual played in, $R$ is the matrix of dummies for the round played, $X$ is the full set of individual characteristics, and $\varepsilon$ is the error term. This is run for all individuals with each round, so the standard errors are clustered at the individual level.

The results of this analysis are presented in Table 5 . None of the individual characteristics predict who trades and who does not. Only receiving a price outside of equilibrium predicts who trades. As equilibrium analysis would suggest, the effect of receiving a bad price is large, negative, and very significant. 


\subsection{Market Trader Characteristics}

To test what individual characteristics make a good trader, I estimate the following model:

$$
Y_{i r}=\beta X_{i}+\varepsilon_{i r}
$$

Where $i$ is the individual, $r$ is the round, $Y$ is the amount of rent person $i$ receives in round $r, X$ is the full set of individual characteristics, and $\varepsilon$ is the error term. Standard errors are clustered at the individual level.

As the prices were given randomly, and it is only prices that predict who trades, I also use outside of equilibrium price to identify a two-step Heckman selection model for whether someone traded, as in List (2004) and Bulte, et al. (2013). The results are very similar to the OLS model.

Results for the full sample are presented in Table 6, columns 1 and 2. The difference in rents between buyers and sellers is around 320 USH per round and is very significant. This represents slightly less than half of the average rents per round and suggests that buyers had significantly higher power in bargaining than sellers did, consistent with the Rubinstein sequential bargaining game presented in Section 3.

In addition, age is significant, suggesting that experience is helpful in making negotiations. Human capital is likewise significant and robust. Combined together, the results suggest that experience and intelligence are strongly related to outcomes.

Similar to List's findings (2004), men and women do not perform differently. The remaining characteristic variables, wealth, preferences, pro-social and anti-social behavior, and aggression, are not significant for either specification. These results suggest that "hard skills" are all that matter for individual bargaining success, while other individual characteristics do not.

The differential market power between buyers and sellers, however, suggests there may be a different set of characteristic functions for these players. Columns 3 and 4 of Table 6 look at 
buyer and seller outcomes respectively using the Heckman selection model. The results are striking when compared to the pooled regressions.

For buyers, wealth and patience are both positive and significant, while the effects of age and human capital disappear. Given that buyers had a significant amount of power in the bargaining relationship, it is not surprising that patience leads to better outcomes. More surprising is wealth, which may be partially enabling of a person to be patient for outcomes.

For sellers, the results are nearly the opposite. Human capital, anti-social behavior and aggression are all positive and significant. Given their lack of market power, it appears that intelligence is important for increasing outcomes. Interestingly, two negative social characteristics, anti-social behavior and aggression, are positively associated with outcomes. This suggests that these characteristics are needed to succeed in a situation where market power is low and it is difficult to extract rents.

\section{Long-Term Predictors of Success}

Finally, I explore the ability of the bargaining game results to predict future outcomes for individuals. I next estimate the following model.

$$
W_{i}=\alpha Y_{i}+\beta X_{i}+\varepsilon_{i}
$$

Where $i$ is the individual, $W$ is a wealth index collected two years after the bargaining games were run, $Y$ is the amount of total rent person $i$ received in all rounds, $X$ is the full set of individual characteristics and $\varepsilon$ is the error term.

The results are presented in Table 7. Consistent with the results of Blattman, Fiala and Martinez (2013), almost all of the characteristics are significant predictors of wealth. The results for total rents from the games shows a positive association with income. Those who performed better in the game also have higher income levels. Despite the sample size being small, these values are 
significant at the $99 \%$ level and robust to the inclusion or exclusion of control variables. An increase of 1,000 USH in rents from the bargaining game is associated with between a 0.02 and 0.05 standard deviation increase in wealth. Alternatively, a one standard deviation increase in performance in the bargaining game $(1,700 \mathrm{USH})$ is associated with between a 0.03 and 0.09 standard deviation increase in wealth.

The results are not significantly different between buyers and sellers, though the outcome for sellers is slightly higher, perhaps reflecting the extra effort that sellers would have needed to perform well in the game. Overall, a one standard deviation increase in rents from the game is associated with between a 0.07 and 0.16 standard deviation increase in wealth, two years after the participants played the game.

\section{Conclusion}

This study uses a classic game from economics, but in a novel way. Rather than looking solely at whether or not market efficiency is reached, I explore individual characteristics and correlate them with market and individual outcomes.

The results of the bargaining experiment described here are largely consistent with general equilibrium and bargaining theory: individual markets, even in a developing country, are largely efficient, and first movers have significantly greater bargaining power in the market. Individual characteristics are also found to be strong predictors of the efficiency of the market, and individual bargaining success. Wealth and patience are important for market powerful buyers, and intelligence, aggression and anti-social behavior important for sellers. The results from the games also predict individual wealth two years after the games were run. This suggests that the skills that facilitate successful market interaction translate into economic outcomes.

The results are thus largely positive for classical economic models, even when applied to developing countries. The results also point to some important elements of success in markets for communities and individuals. Markets are less common in developed economics, but across the 
developing world they are an individual's main form of economic interaction. A better understanding of what makes a good negotiator in a market will help to open the black box of market interaction and development. 


\section{References}

Bates, Timothy (1990) "Self-Employment Trends Among Mexican Americans," Working Papers 90-9, Center for Economic Studies, U.S. Census Bureau.

Benjamin Daniel, Sebastian Brown and Jesse Shapiro (2013) "Who is "behavioral"? Cognitive ability and anomalous preferences," Journal of the European Economic Association, Forthcoming.

Bloom, Nick and John Van Reenen (2007) “Measuring and Explaining Management Practices Across Firms and Nations," Quarterly Journal of Economics 122 (4), 1351-1408.

Bulte, Erwin, Andreas Kontoleon, John List, Ty Turleyc and Maarten Voorsb (2013) "When Economics Meets Hierarchy: A Field Experiment on the Workings of the Invisible Hand," Working Paper.

Casari, Marco, John C. Ham and John H. Kagel (2007) "Selection Bias, Demographic Effects, and Ability Effects in Common Value Auction Experiments," American Economic Review, American Economic Association, vol. 97(4), pages 1278-1304, September.

Casson, M. (2003) The Entrepreneur: An Economic Theory, second edition", Edward Elgar Publishing.

DellaVigna, Stefano (2009) "Psychology and Economics: Evidence from the Field." Journal of Economic Literature, 47(2): 315-72.

Djankov, Simeon, Yingyi Qian, Gerard Roland and Ekaterina Zhuravskaya (2007) "What Makes a Successful Entrepreneur? Evidence from Brazil," Working Papers w0104, Center for Economic and Financial Research (CEFIR).

Dohmen, Thomas, Armin Falk, David Huffman and Uwe Sunde (2006) "Homo Reciprocans: Survey Evidence on Prevalence, Behavior and Success," IZA Discussion Papers 2205, Institute for the Study of Labor (IZA). 
Einav, Liran, Chiara Farronato, Jonathan Levin and Neel Sundaresany (2013) "Sales Mechanisms in Online Markets: What Happened to Internet Auctions," Working Paper.

Fama, Eugene (1970) "Efficient Capital Markets: A Review of Theory and Empirical Work," Journal of Finance, Vol.25, No.2, pp.383-417.

Garvin, Susan and Kagel, John H. (1994) "Learning in common value auctions: Some initial observations," Journal of Economic Behavior \& Organization, Elsevier, vol. 25(3), pages 351-372, December.

Gneezy, Uri, Muriel Niederle and Aldo Rustichini (2003) "Performance in Competitive Environments: Gender Differences," Quarterly Journal of Economics 118 (3): 1049-1074.

Ham, John C. \& Kagel, John H. (2006) “Gender effects in private value auctions," Economics Letters, Elsevier, vol. 92(3), pages 375-382, September.

Heckman, James, Jora Stixrud and Sergio Urzua (2006) "The Effects of Cognitive and Noncognitive Abilities on Labor Market Outcomes and Social Behavior," Journal of Labor Economics, vol. 24(3), pages 411-482, July.

Iyer, Rajkamal and Antoinette Schoar (2010) "Are there Cultural Determinants of Entrepreneurship?," NBER Chapters, in: International Differences in Entrepreneurship, pages 209-240 National Bureau of Economic Research, Inc.

Kagel, John and Jean-Francois Richard (2001) "Super-Experienced Bidders In First-Price Common-Value Auctions: Rules Of Thumb, Nash Equilibrium Bidding, And The Winner's Curse," The Review of Economics and Statistics, MIT Press, vol. 83(3), pages 408-419, August.

List, John (2004) "Testing Neoclassical Competitive Theory in Multilateral Decentralized Markets," Journal of Political Economy, University of Chicago Press, vol. 112(5), pages 1131-1156, October. 
Magnusson, Magnus and Bruce Wydick (2002) "How efficient are Africa's emerging stock markets?" Journal of Development Studies, 38 (4), pp. 141-156(16).

Rubinstein, Ariel (1982) "Perfect Equilibrium in a Bargaining Model," Econometrica 50 (1): 97109.

Smith, Vernon (1962) “An Experimental Study of Competitive Market Behavior," Journal of Political Economy 70: 111-137. 
Figure 1: Theoretical outcome prediction

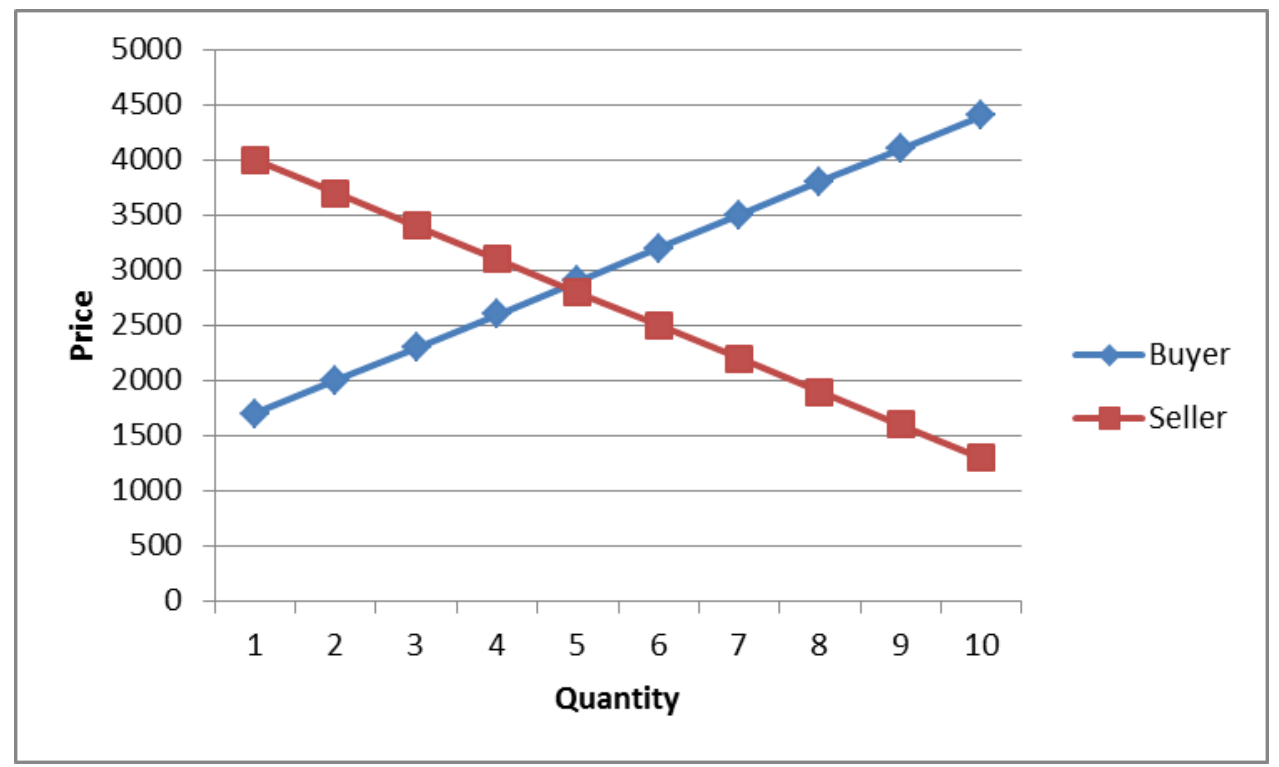


Figure 2: Efficiency rates by round

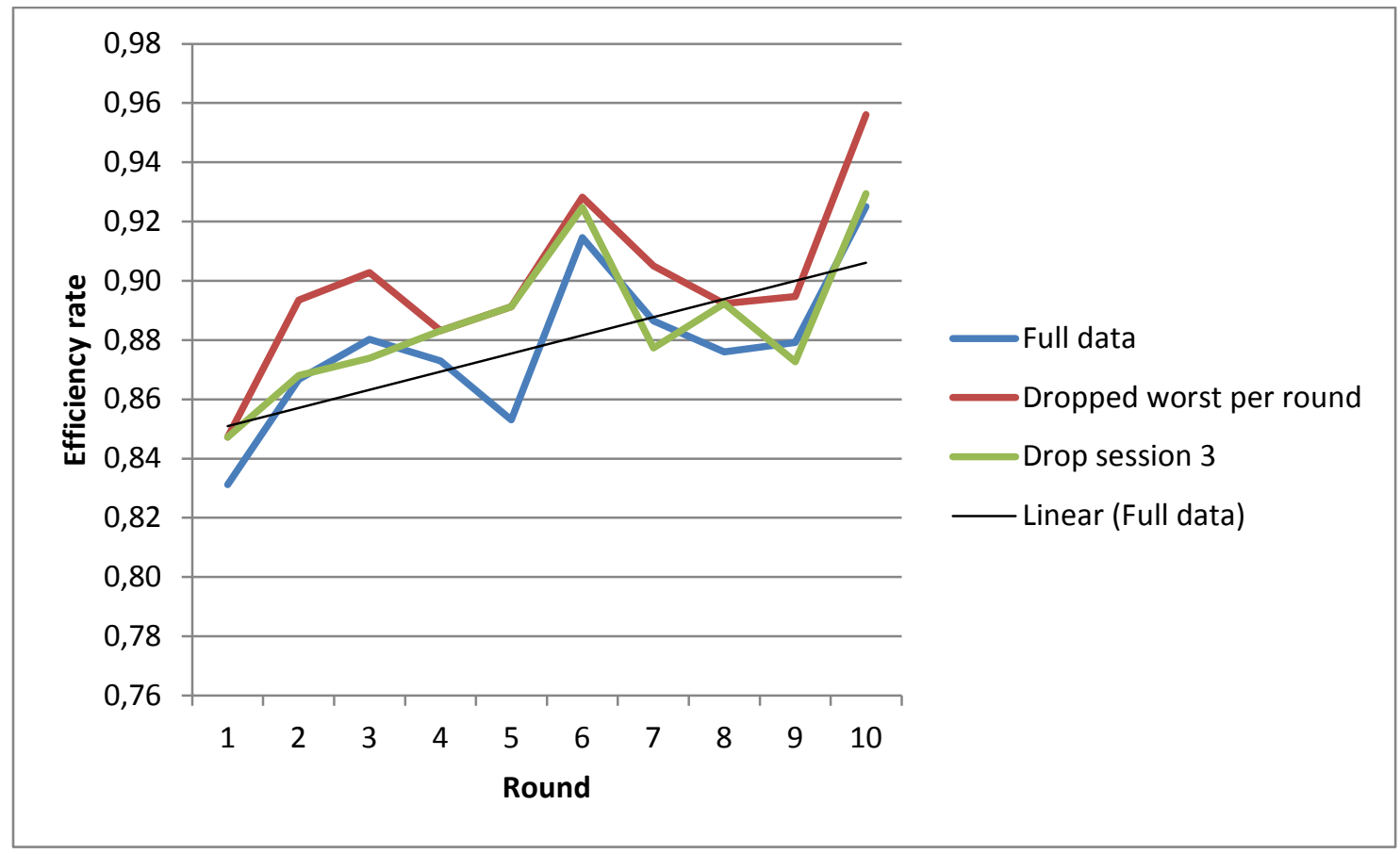


Figure 3: Density of efficiency rates by round

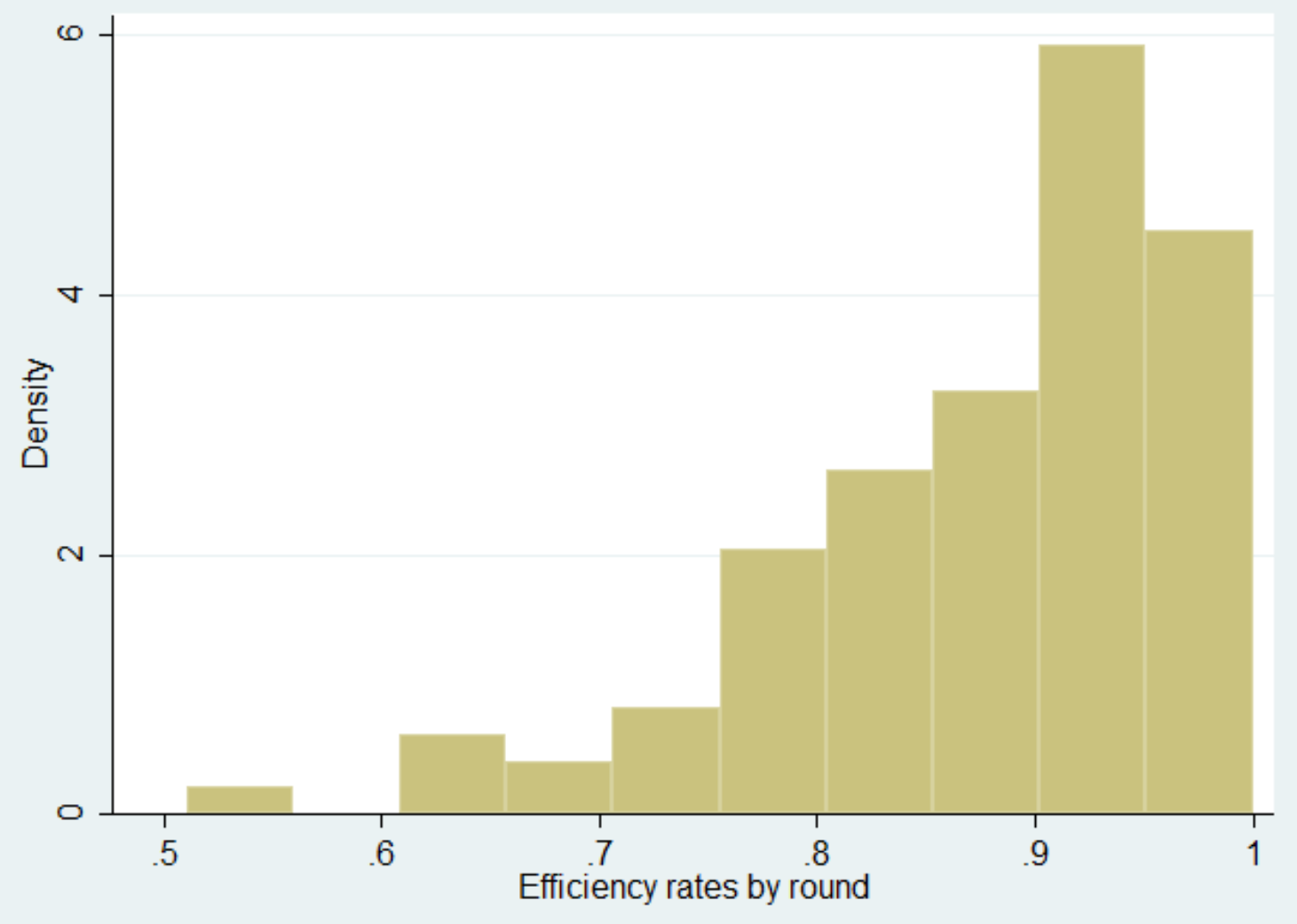


Table 1: Bargaining game summary statistics

\begin{tabular}{|c|c|c|c|c|c|c|c|c|c|c|c|}
\hline & \multicolumn{11}{|l|}{ Round } \\
\hline & 1 & 2 & 3 & 4 & 5 & 6 & 7 & 8 & 9 & 10 & All \\
\hline Average price & 2,729 & 2,631 & 2,565 & 2,634 & 2,708 & 2,764 & 2,717 & 2,782 & 2,773 & 2,725 & 2,703 \\
\hline Max price & 4,000 & 4,100 & 4,000 & 3,800 & 3,900 & 4,000 & 4,100 & 4,150 & 4,100 & 4,100 & \\
\hline Min price & 1,500 & 1,600 & 1,500 & 1,500 & 1,400 & 1,900 & 1,600 & 1,600 & 1,800 & 1,400 & \\
\hline SD price & 571 & 608 & 539 & 534 & 577 & 507 & 542 & 544 & 556 & 432 & \\
\hline Average rent & 694 & 705 & 728 & 693 & 671 & 714 & 703 & 647 & 686 & 746 & 699 \\
\hline Min rent & $-2,000$ & -900 & -800 & $-1,100$ & $-1,500$ & -600 & $-2,000$ & 100 & 50 & 50 & \\
\hline Max rent & 2,900 & 2,200 & 2,800 & 1,900 & 2,200 & 2,200 & 2,400 & 1,800 & 2,100 & 2,700 & \\
\hline SD rent & 661 & 506 & 562 & 532 & 579 & 506 & 540 & 449 & 467 & 515 & \\
\hline Actual group rent & 7,980 & 8,320 & 8,450 & 8,380 & 8,190 & 8,780 & 8,510 & 8,410 & 8,440 & 8,880 & 8,434 \\
\hline$\%$ of max rent & $83 \%$ & $87 \%$ & $88 \%$ & $87 \%$ & $85 \%$ & $91 \%$ & $89 \%$ & $88 \%$ & $88 \%$ & $93 \%$ & $88 \%$ \\
\hline
\end{tabular}


Table 2: Individual summary statistics

\begin{tabular}{llllll}
\hline \hline Variable & $\mathrm{N}$ & Mean & Std. Dev. & Min & Max \\
\hline & & & & & \\
Total rents in '000 & 128 & 4.075 & 1.734 & 0.5 & 8.4 \\
Ln baseline income & 128 & 7.751 & 2.492 & 3.130 & 11.984 \\
Age & 128 & 25.180 & 5.863 & 16 & 56 \\
Female & 128 & 0.289 & 0.454 & 0 & 1 \\
Human capital index & 128 & -0.061 & 0.601 & -1.985 & 1.566 \\
Wealth index & 128 & -0.080 & 0.661 & -0.879 & 2.754 \\
Risk aversion index & 128 & -0.004 & 0.424 & -1.192 & 0.836 \\
Patience index & 128 & 0.044 & 0.485 & -1.066 & 1.391 \\
Pro-social index & 128 & 23.797 & 3.614 & 16 & 30 \\
Anti-social index & 128 & 0.191 & 0.896 & -2.516 & 2.092 \\
Aggression index & 128 & -0.270 & 0.860 & -1.425 & 2.343 \\
\hline \hline
\end{tabular}


Table 3: Round efficiency

\begin{tabular}{|c|c|c|c|c|}
\hline & Round efficiency & Round efficiency & Round efficiency & Round efficiency \\
\hline & Full sample & $\begin{array}{l}\text { Truncated top } \\
5 \%\end{array}$ & $\begin{array}{l}\text { Truncated bottom } \\
5 \%\end{array}$ & $\begin{array}{l}\text { Truncated top } \\
\text { and bottom 5\% }\end{array}$ \\
\hline \multirow[t]{2}{*}{ Mean age } & $0.022 * *$ & $0.021 * *$ & $0.014^{*}$ & $0.015^{* *}$ \\
\hline & {$[0.021]$} & {$[0.024]$} & [0.053] & {$[0.048]$} \\
\hline \multirow[t]{2}{*}{ Percent female } & $0.212+$ & 0.187 & 0.133 & 0.150 \\
\hline & {$[0.121]$} & [0.179] & {$[0.235]$} & {$[0.175]$} \\
\hline \multirow[t]{2}{*}{ Mean human capital index } & $0.331 * *$ & $0.262^{*}$ & $0.325 * *$ & $0.358 * * *$ \\
\hline & {$[0.021]$} & {$[0.098]$} & {$[0.012]$} & {$[0.002]$} \\
\hline \multirow[t]{2}{*}{ Mean wealth index } & $0.102^{*}$ & $0.091+$ & 0.051 & 0.061 \\
\hline & {$[0.076]$} & {$[0.115]$} & {$[0.259]$} & {$[0.174]$} \\
\hline \multirow[t]{2}{*}{ Mean risk aversion index } & -0.114 & -0.061 & -0.136 & -0.166 \\
\hline & {$[0.560]$} & {$[0.763]$} & {$[0.396]$} & {$[0.285]$} \\
\hline \multirow[t]{2}{*}{ Mean patience index } & $-0.521 * *$ & $-0.500 * *$ & $-0.333^{*}$ & $-0.338^{*}$ \\
\hline & {$[0.030]$} & {$[0.040]$} & {$[0.084]$} & {$[0.074]$} \\
\hline \multirow[t]{2}{*}{ Mean pro-social index } & $-0.220 * * *$ & $-0.202 * *$ & $-0.154 * *$ & $-0.162 * *$ \\
\hline & [0.009] & {$[0.020]$} & {$[0.027]$} & {$[0.016]$} \\
\hline \multirow[t]{2}{*}{ Mean anti-social index } & $-1.663 * * *$ & $-1.534 * *$ & $-1.226 * *$ & $-1.270 * * *$ \\
\hline & {$[0.006]$} & [0.015] & {$[0.016]$} & [0.009] \\
\hline \multirow[t]{2}{*}{ Mean aggression index } & $-2.051 * * *$ & $-1.900 * *$ & $-1.460 * *$ & $-1.512^{* *}$ \\
\hline & [0.007] & {$[0.016]$} & [0.021] & {$[0.012]$} \\
\hline \multirow[t]{2}{*}{ Round } & $0.006^{*}$ & $0.006^{*}$ & 0.004 & 0.004 \\
\hline & [0.067] & [0.081] & {$[0.165]$} & [0.172] \\
\hline Observations & 100 & 95 & 95 & 90 \\
\hline R-squared & 0.153 & 0.121 & 0.153 & 0.203 \\
\hline
\end{tabular}

Robust $\mathrm{p}$-values are in brackets. Statistical significance is reported as: ${ }^{* * *} \mathrm{p}<0.01, * * \mathrm{p}<0.05,{ }^{*}$ $p<0.10,+p<0.15$. 
Table 4: Balance test

\begin{tabular}{|c|c|c|c|c|c|c|c|c|c|}
\hline & Age & Female & $\begin{array}{l}\text { Human } \\
\text { capital } \\
\text { index }\end{array}$ & $\begin{array}{l}\text { Wealth } \\
\text { index }\end{array}$ & $\begin{array}{l}\text { Risk } \\
\text { aversion } \\
\text { index }\end{array}$ & $\begin{array}{l}\text { Patience } \\
\text { index }\end{array}$ & $\begin{array}{l}\text { Pro- } \\
\text { social } \\
\text { index }\end{array}$ & $\begin{array}{l}\text { Anti- } \\
\text { social } \\
\text { index }\end{array}$ & $\begin{array}{l}\text { Aggression } \\
\text { index }\end{array}$ \\
\hline Buyer dummy & $\begin{array}{l}-0.792 \\
{[0.486]}\end{array}$ & $\begin{array}{l}0.005 \\
{[0.965]}\end{array}$ & $\begin{array}{l}0.075 \\
{[0.455]}\end{array}$ & $\begin{array}{l}-0.048 \\
{[0.572]}\end{array}$ & $\begin{array}{l}0.063 \\
{[0.170]}\end{array}$ & $\begin{array}{l}0.043 \\
{[0.513]}\end{array}$ & $\begin{array}{l}0.263 \\
{[0.668]}\end{array}$ & $\begin{array}{l}-0.130 \\
{[0.355]}\end{array}$ & $\begin{array}{l}0.146 \\
{[0.292]}\end{array}$ \\
\hline Observations & 1,280 & 1,280 & 1,280 & 1,280 & 1,280 & 1,280 & 1,280 & 1,280 & 1,280 \\
\hline R-squared & 0.169 & 0.095 & 0.284 & 0.389 & 0.550 & 0.502 & 0.036 & 0.138 & 0.146 \\
\hline
\end{tabular}

Robust $\mathrm{p}$-values are in brackets. Statistical significance is reported as: ${ }^{* * *} \mathrm{p}<0.01,{ }^{* *} \mathrm{p}<0.05,{ }^{*}$ $p<0.10,+p<0.15$. 
Table 5: Determinants of trading

\begin{tabular}{|c|c|c|c|}
\hline & $\begin{array}{l}\text { Pooled } \\
\text { If trade }\end{array}$ & $\begin{array}{l}\text { Buyer } \\
\text { If trade }\end{array}$ & $\begin{array}{l}\text { Seller } \\
\text { If trade }\end{array}$ \\
\hline \multirow[t]{2}{*}{ Bad price } & $-0.672 * * *$ & $-0.644 * * *$ & $-0.696 * * *$ \\
\hline & {$[0.000]$} & {$[0.000]$} & {$[0.000]$} \\
\hline \multirow[t]{2}{*}{ Age } & -0.001 & 0.002 & -0.003 \\
\hline & {$[0.704]$} & {$[0.628]$} & {$[0.239]$} \\
\hline \multirow[t]{2}{*}{ Female } & -0.018 & -0.021 & -0.014 \\
\hline & {$[0.566]$} & {$[0.724]$} & {$[0.746]$} \\
\hline \multirow[t]{2}{*}{ Human capital index } & 0.026 & 0.041 & 0.021 \\
\hline & {$[0.184]$} & {$[0.243]$} & {$[0.424]$} \\
\hline \multirow[t]{2}{*}{ Wealth index } & 0.022 & 0.024 & 0.002 \\
\hline & {$[0.231]$} & [0.302] & {$[0.932]$} \\
\hline \multirow[t]{2}{*}{ Risk aversion index } & -0.040 & -0.033 & -0.069 \\
\hline & {$[0.310]$} & {$[0.719]$} & {$[0.174]$} \\
\hline \multirow[t]{2}{*}{ Patience index } & -0.004 & -0.023 & 0.004 \\
\hline & {$[0.850]$} & [0.602] & {$[0.905]$} \\
\hline \multirow[t]{2}{*}{ Pro-social index } & -0.003 & 0.000 & -0.006 \\
\hline & {$[0.454]$} & {$[0.916]$} & {$[0.316]$} \\
\hline \multirow[t]{2}{*}{ Anti-social index } & -0.054 & $-0.130 * * *$ & 0.061 \\
\hline & [0.317] & {$[0.001]$} & [0.413] \\
\hline \multirow{2}{*}{ Aggression index } & -0.067 & $-0.114^{* *}$ & 0.022 \\
\hline & {$[0.225]$} & {$[0.014]$} & {$[0.787]$} \\
\hline Observations & 1,410 & 670 & 740 \\
\hline R-squared & 0.460 & 0.431 & 0.501 \\
\hline
\end{tabular}

Robust $\mathrm{p}$-values are in brackets. Statistical significance is reported as: $* * * p<0.01, * * p<0.05, *$ $p<0.10,+p<0.15$ 
Table 6: Rents

\begin{tabular}{|c|c|c|c|c|}
\hline & $\begin{array}{l}\text { Pooled } \\
\text { OLS } \\
\text { Rents }\end{array}$ & $\begin{array}{l}\text { Pooled } \\
\text { Heckman } \\
\text { Rents }\end{array}$ & $\begin{array}{l}\text { Buyer } \\
\text { Heckman } \\
\text { Rents }\end{array}$ & $\begin{array}{l}\text { Seller } \\
\text { Heckman } \\
\text { Rents }\end{array}$ \\
\hline Bad price & $\begin{array}{l}-405.228^{* * *} \\
{[0.000]}\end{array}$ & $\begin{array}{l}-2.150 * * * \\
{[0.000]}\end{array}$ & $\begin{array}{l}-2.082 * * * \\
{[0.000]}\end{array}$ & $\begin{array}{l}-2.217^{* * *} \\
{[0.000]}\end{array}$ \\
\hline Buyer & $\begin{array}{l}320.433^{* * *} \\
{[0.000]}\end{array}$ & $\begin{array}{l}322.768^{* * *} \\
{[0.000]}\end{array}$ & & \\
\hline Age & $\begin{array}{l}-7.432+ \\
{[0.107]}\end{array}$ & $\begin{array}{l}-7.367^{*} \\
{[0.094]}\end{array}$ & $\begin{array}{l}-15.584^{* *} \\
{[0.033]}\end{array}$ & $\begin{array}{l}-2.067 \\
{[0.592]}\end{array}$ \\
\hline Female & $\begin{array}{l}-30.676 \\
{[0.299]}\end{array}$ & $\begin{array}{l}-32.094 \\
{[0.268]}\end{array}$ & $\begin{array}{l}-8.282 \\
{[0.906]}\end{array}$ & $\begin{array}{l}-15.412 \\
{[0.546]}\end{array}$ \\
\hline Human capital index & $\begin{array}{l}85.033^{* *} \\
{[0.037]}\end{array}$ & $\begin{array}{l}84.483^{* *} \\
{[0.026]}\end{array}$ & $\begin{array}{l}1.474 \\
{[0.983]}\end{array}$ & $\begin{array}{l}139.291^{* * *} \\
{[0.000]}\end{array}$ \\
\hline Wealth index & $\begin{array}{l}3.536 \\
{[0.922]}\end{array}$ & $\begin{array}{l}2.156 \\
{[0.951]}\end{array}$ & $\begin{array}{l}67.193+ \\
{[0.137]}\end{array}$ & $\begin{array}{l}-32.216 \\
{[0.322]}\end{array}$ \\
\hline Risk aversion index & $\begin{array}{l}62.427 \\
{[0.305]}\end{array}$ & $\begin{array}{l}61.046 \\
{[0.303]}\end{array}$ & $\begin{array}{l}102.290 \\
{[0.300]}\end{array}$ & $\begin{array}{l}-73.275 \\
{[0.317]}\end{array}$ \\
\hline Patience index & $\begin{array}{l}83.740 \\
{[0.152]}\end{array}$ & $\begin{array}{l}80.033+ \\
{[0.148]}\end{array}$ & $\begin{array}{l}160.858^{* *} \\
{[0.046]}\end{array}$ & $\begin{array}{l}-15.447 \\
{[0.773]}\end{array}$ \\
\hline Pro-social index & $\begin{array}{l}3.208 \\
{[0.563]}\end{array}$ & $\begin{array}{l}3.175 \\
{[0.556]}\end{array}$ & $\begin{array}{l}3.070 \\
{[0.789]}\end{array}$ & $\begin{array}{l}1.097 \\
{[0.840]}\end{array}$ \\
\hline Anti-social index & $\begin{array}{l}24.176 \\
{[0.732]}\end{array}$ & $\begin{array}{l}27.572 \\
{[0.685]}\end{array}$ & $\begin{array}{l}-55.388 \\
{[0.608]}\end{array}$ & $\begin{array}{l}103.355^{*} \\
{[0.091]}\end{array}$ \\
\hline Aggression index & $\begin{array}{l}26.271 \\
{[0.752]}\end{array}$ & $\begin{array}{l}29.725 \\
{[0.711]}\end{array}$ & $\begin{array}{l}-57.999 \\
{[0.668]}\end{array}$ & $\begin{array}{l}117.112^{*} \\
{[0.069]}\end{array}$ \\
\hline $\begin{array}{l}\text { Observations } \\
\text { R-squared }\end{array}$ & $\begin{array}{l}824 \\
0.209\end{array}$ & 1,616 & 786 & 830 \\
\hline
\end{tabular}

Robust $p$-values are in brackets. Statistical significance is reported as: $* * * p<0.01, * * p<0.05, *$ $p<0.10,+p<0.15$. 
Table 7: Wealth outcome, 2 years after bargaining game

\begin{tabular}{|c|c|c|c|c|c|c|}
\hline & $\begin{array}{l}\text { Pooled } \\
\text { Ln income } \\
\text { last } 4 \text { weeks }\end{array}$ & $\begin{array}{l}\text { Ln income } \\
\text { last } 4 \text { weeks }\end{array}$ & $\begin{array}{l}\text { Buyers } \\
\text { Ln income } \\
\text { last } 4 \text { weeks }\end{array}$ & $\begin{array}{l}\text { Ln income } \\
\text { last } 4 \text { weeks }\end{array}$ & $\begin{array}{l}\text { Sellers } \\
\text { Ln income } \\
\text { last } 4 \text { weeks }\end{array}$ & $\begin{array}{l}\text { Ln income } \\
\text { last } 4 \text { weeks }\end{array}$ \\
\hline Total rents in '000 & $\begin{array}{l}0.055^{* * *} \\
{[0.000]}\end{array}$ & $\begin{array}{l}0.024^{*} \\
{[0.076]}\end{array}$ & $\begin{array}{l}0.064^{* * *} \\
{[0.001]}\end{array}$ & $\begin{array}{l}0.038^{* *} \\
{[0.041]}\end{array}$ & $\begin{array}{l}0.091^{* * *} \\
{[0.001]}\end{array}$ & $\begin{array}{l}0.090^{* * *} \\
{[0.003]}\end{array}$ \\
\hline Age & & $\begin{array}{l}0.028^{* * *} \\
{[0.000]}\end{array}$ & & $\begin{array}{l}0.024^{* * *} \\
{[0.000]}\end{array}$ & & $\begin{array}{l}0.023^{* * *} \\
{[0.000]}\end{array}$ \\
\hline Female & & $\begin{array}{l}0.126^{* *} \\
{[0.022]}\end{array}$ & & $\begin{array}{l}0.121^{*} \\
{[0.065]}\end{array}$ & & $\begin{array}{l}0.269 * * * \\
{[0.001]}\end{array}$ \\
\hline Human capital index & & $\begin{array}{l}0.541^{* * *} \\
{[0.000]}\end{array}$ & & $\begin{array}{l}0.911^{* * *} \\
{[0.000]}\end{array}$ & & $\begin{array}{l}0.238^{* * *} \\
{[0.000]}\end{array}$ \\
\hline Wealth index & & $\begin{array}{l}0.010 \\
{[0.820]}\end{array}$ & & $\begin{array}{l}-0.076 \\
{[0.180]}\end{array}$ & & $\begin{array}{l}-0.138^{* *} \\
{[0.047]}\end{array}$ \\
\hline Risk aversion index & & $\begin{array}{l}-0.159 * * \\
{[0.045]}\end{array}$ & & $\begin{array}{l}-0.329 * * * \\
{[0.001]}\end{array}$ & & $\begin{array}{l}0.295^{* *} \\
{[0.016]}\end{array}$ \\
\hline Patience index & & $\begin{array}{l}0.115^{*} \\
{[0.088]}\end{array}$ & & $\begin{array}{l}-0.092 \\
{[0.228]}\end{array}$ & & $\begin{array}{l}0.190^{*} \\
{[0.067]}\end{array}$ \\
\hline Pro-social index & & $\begin{array}{l}-0.006 \\
{[0.448]}\end{array}$ & & $\begin{array}{l}-0.002 \\
{[0.855]}\end{array}$ & & $\begin{array}{l}0.015+ \\
{[0.143]}\end{array}$ \\
\hline Anti-social index & & $\begin{array}{l}-0.128 \\
{[0.200]}\end{array}$ & & $\begin{array}{l}-0.109 \\
{[0.368]}\end{array}$ & & $\begin{array}{l}-0.597 * * * \\
{[0.000]}\end{array}$ \\
\hline Aggression index & & $\begin{array}{l}-0.253^{* *} \\
{[0.018]}\end{array}$ & & $\begin{array}{l}-0.150 \\
{[0.246]}\end{array}$ & & $\begin{array}{l}-0.687^{* * *} \\
{[0.000]}\end{array}$ \\
\hline Observations & 128 & 128 & 63 & 63 & 65 & 65 \\
\hline R-squared & 0.149 & 0.278 & 0.398 & 0.594 & 0.144 & 0.254 \\
\hline
\end{tabular}

Robust $p$-values are in brackets. Statistical significance is reported as: ${ }^{* * *} p<0.01,{ }^{* *} p<0.05,{ }^{*}$ $p<0.10,+p<0.15$. 


\section{APPENDIX: GAMES PROTOCOLS}

\section{INTRODUCTIONS \& GENERAL INSTRUCTIONS}

\section{Protocol Checklist}

1. Have you found a private location for the group activities away from other people?

2. Do you have an open location for members to bargain?

3. Do you have the completed roster and the set of verification question data for this group?

4. Do you have all of the following materials required for the auction game and the network/price game?

\section{Completed roster}

2. Sign-in sheet

3. Initial pay-out form

4. Buyer and seller nametags

5. Pins to attach nametags

6. Individual feedback sheets

7. Folders/clipboards for feedback sheets

8. Pens for individual use during feedback process

9. Buyer and seller price cards (Rounds 1-10)

10. Transaction report forms (Have 100 available)

11. Trade failure report forms (Have 10 available)

12. Large envelope for completed forms

13. Stapler and extra staples

14. Network information game introduction form

15. Money for network allowance and transport refund

16. Allowance sign-out sheet

\section{Speak to the entire group:}

Thank you all for taking the time to come today. Before we start today's activity, I would like to speak with each of you individually for registration. When everyone has registered, we will begin our activity together.

\section{Registration and Identity verification procedure:}

Call players to the front table individually. Discuss the consent information on the following page with each respondent and complete the check-in roster using the steps outlined below: 
Collect the invitation letter from each respondent and make sure he/she has come to the correct session. Match each individual registering with the invitation roster and check them off on the list.

Next complete the check-in form: Ask the respondent the verification questions provided and check that their answers match with the baseline data you have been given. Also ask the respondent to sign the check-in roster. Compare the signature on the check-in roster with the signature on the registration form. If the signatures do not match or the verification answers are incorrect, please probe further to ensure that this individual is the same person who was to be invited.

Should you find that this person is a different individual, ask the individual to please wait until the registration process has been completed. A number of alternates have been invited to each session. If you are able to confirm the identity of 20 individuals, then you may dismiss those who have not passed the identity verification. If there are less than 20 confirmed respondents, unconfirmed individuals may remain to ensure there is a full set of participants, but their data will not be used. Make sure to note clearly on the check-in roster that their identity was not verified.

After an individual has consented to the survey and his/her identity has been verified, invite the participant to choose a buyer/seller card from the bucket. This will be the individual's "Player Number." Record the number in the last column on the check-in sheet. It is essential that the player remembers this number, as it will be used to identify him/her throughout the auction and network games, and will be how we identify players for their payment the following week.

Provide the player with a pin and instruct him to display his buyer/seller number in an obvious way on his shirt. Also provide a pen and the folder/clipboard with the individual feedback form (folded to hide responses for privacy). Make sure to record the player number on the feedback form before giving it to the respondent.

In case less than 20 individuals arrive by 30 minutes after the scheduled game start time, you will need to find alternative participants from around the sub-county center. Invite any available youth-aged individuals so that you have 20 available participants.

Should more than 20 confirmed individuals arrive on-time for the game, complete the check-in process with respondents in the order of their arrival. Do not dismiss anyone until you have 20 confirmed and verified players. Once 20 players have checked in, you may send any other individuals home. We will still provide transport refunds to additional players who arrived on-time with their original invitation cards. These players should sign for their transport allowance on the "Initial Payout Register" form, which you will attach to the check-in roster at the end of the game session.

At the conclusion of the check-in process, be sure to save both the invitation roster and the check in sheet. You will add these to the payment receipt sheet at the end of the games. These forms are essential to track respondents for payment and data analysis. 


\section{Individual Player Consent Script:}

I want to ask you if you will participate in a special activity. This activity involves real money, some of which you will take home.

Before we continue, let me stress something that is very important. I know you were invited here without understanding very much about what we are planning to do today. If at any time you find that this is something that you do not wish to participate in for any reason, you are free to leave whether we have started the activities or not.

This activity will take about 2 hours to complete, so if you think you will not be able to stay that long without leaving please let me know now. Will you be able to stay for two hours?

The money you receive today will depend on the decisions you make and the decisions other members present today make. We will not give out money after each activity. Instead, we will process your payments in the next week and will return to your sub-county exactly one week from today. We will announce the exact date and time for each sub-county at the end of today's session. You will receive the money you made based on the decisions in the activities today.

Everything you do and say will remain confidential. Only the lead researcher will know your identity. No one else, including local staff or any government agencies, will know your identity.

Do you have any questions, or would you like more information about the activities?

[Answer questions]

If I have answered all of your questions, may I ask you to participate in the activities?

IF NO, DO NOT CONTINUE: I understand. Thank you for coming today.

\section{IF YES:}

Are you sure you will be available for the next two hours? If you think you may have to leave sooner, please let me know now.

[Politely inform the individual that they must be able to stay for the entire 2 hour session in order to participate. If they are unable to do so, thank them for their time, but dismiss them.]

Thank you. Remember, if at any time you wish to stop, you are free to leave.

Now complete the check-in roster and follow the procedures outlined above. 


\section{$\underline{\text { Introduction }}$}

Once again, thank you all for coming today. I am [NAME], this is [NAME] and [NAME], and we are working with an international research NGO based in the United States. Our team is trying to understand the way people plan and make business decisions, how people work together, and what networks people have. There are no right or wrong answers. We are going to play a market game. If at any time you have questions, please feel free to ask any member of our team.

We will be simulating a market in town. Ten of you are going to be buyers and ten of you are going to be sellers. The card you drew from the bucket during registration identifies your role. Please make sure this is pinned somewhere very visibly on your shirt.

In our market today, our sellers will be selling a number of items, trying to get the best possible price from the buyers. Each of you will get a card before each round. This card will have a price on it. Sellers, this represents the amount that you paid for the item. You cannot sell the item for less than the amount on your card. If you were to sell it any lower, you would be losing money. It is to your advantage to sell the item for as high a price as possible. The higher a price you sell the item for, the more you will profit. After each round we will record your profits. You will get to keep this money at the end of the game. The better you are at negotiating, the more money you will win.

For example, let's say you are selling slippers and your card says 2,000 shillings. The amount on your card indicates how much you paid for that pair of slippers. The more you are able to charge above this price, the greater your profit will be. For example, if you sell the slippers for 2,800 shillings, your profit will be 800 shillings and you will get to actually keep this money. You could sell the slippers to your customer for any price more than 2,000 shillings, but this is the absolute minimum you could charge. You could not possibly sell the slippers for less than 2,000 because then you would be losing money.

Buyers, you will attempt to buy these items for the best price you can negotiate. The card you receive lets you know how much money you have in your pocket. You can spend up to that amount of money, but no more than what it says on the card. If you spend less money than the amount on the card, you will get to keep anything that is remaining. For example, let's say you are in the market for a new pair of slippers. If your card says 3,000 shillings, then that would be the maximum amount of money you could spend. If you are able to negotiate with a seller who will give you the slippers for 2,300 shillings, you will get to keep 700 shillings. You will get to go with this money at the end of the day. You could not possibly pay more than 3,000 shillings for the slipper because you only have 3,000 in your pocket.

Let's do one example to get us started. If Seller A's card says 2,400 shillings that means that he bought the slippers from the wholesaler for 2,400 shillings. Buyer B's card says 3,500 shillings, so she has exactly 3,500 shillings in her pocket. If Seller A and Buyer B meet in the market, they can begin to negotiate for the slippers. 
Now try some questions to test the group's understanding:

Let's say after negotiating that Buyer B agrees to pay seller A 3,000 shillings for the slippers. How much money would Seller A have made as profit? (The correct answer is 600 shillings.)

How much money would Buyer B have remaining in his pocket? (The correct answer is 500 shillings).

Can anyone name another price that Buyer B and Seller A could have agreed upon to sell the slippers? (Any price between 2400 and 3500 is acceptable). Follow-up by asking different participants to calculating profits for each player at the second price. Repeat if many participants still seem unsure.)

What if Seller A really wants to make a sale, so he agrees to sell them to Buyer B at 2,200 shillings? (This would be an illegal trade. Make sure all participants understand why such a trade would not be allowed.)

Let's think about one more example. In this case, Seller A's card still says 2,400 shillings, but this time Buyer B's card says 2,000 shillings. Can anyone name a price now where Buyer B and Seller A could agree upon? (In this case, Seller $A$ and Buyer $B$ will not be able to reach an agreement at any price.) As you can see, you may not always be able to transact with every other buyer or seller in the game. If you find yourself in a situation where you cannot agree on a trade, you are free to begin negotiating with any other buyer or seller.

You see that there are ten buyers and sellers. In every round, the buyers will be free to negotiate with all of the sellers. Sellers, you are welcome to try to convince any buyer to purchase from you. We will give you five minutes to negotiate and come to an agreement. In that time you can talk to as many different buyers or sellers as you would like. I will give you a 1 minute warning when time is almost up. This will be your notification to finalize any transactions.

The card that you receive with your price on it is private information for you alone. When you are negotiating, do not show that card to any other buyers or sellers.

When a buyer and a seller agree to make a trade, both of you should come up to the front together and tell us what price you have agreed on so we can record your profits. Please make an ORDERLY QUEUE behind the table and do not crowd the front. Remember that all trades are private; please be respectful of your fellow players. When you are in line and talking with our clerk, make sure you still do not show your card to anyone else, including the person with whom you have just traded.

You don't have to make a deal or agree with a buyer or seller in every round. Sometimes you may feel like you are not being offered a fair price. Other times, you and your trading partner might not have compatible prices. If you aren't satisfied with the prices you are being offered by the buyers/sellers or if you are unable to reach an agreement, you can choose not to trade. 
There is no penalty for not trading, but you will not make a profit or win any money in the round if you fail to make a trade.

Remember that it is against the rules to buy at a price above the amount on your card or sell for price less than the amount on your card. Should anyone make an illegal trade, that person will be disqualified from the round and will receive no profit. The trading partner will receive the difference between the two cards as profit.

After each round, we will ask just a couple of questions about the game so far. Save the pens and papers we have given you to answer those questions. Make sure to keep the papers folded so no one else sees your answers. I will explain these in a bit more detail after our first round.

We will play the game for a total of ten rounds. We will keep records of every trade that happens today. Our team will then total up your profits when we return to town. will be back to pay you exactly one week from today, at a time we agree up-

on at the end of this session.

Does anyone have any questions about how this game will work?

\section{[Answer questions]}

Okay, now let's begin. You have 5 minutes to discuss with other buyers and sellers. If you choose to make a deal, then once it is completed, come up to the front with your cards. Make sure you have finalized all of your negotiations before I say "time." We will not accept any deals made after time is called.

In the first two rounds, we will allow a small amount of extra time to allow people to become accustomed to the game (but do not tell them this). Allow people to trade for six minutes. Then, give a one minute warning. After 7 minutes, stop any negotiations in progress. Beginning in the third round, strictly keep to time. It is okay to allow a few seconds for pairs to finalize their negotiations after time is called, but if negotiations remain unresolved, the deal should not be recorded.

As players make a deal, collect their cards in pairs. For each successful transaction, complete the "Transaction Report." Record the transaction price and the buyer and seller numbers in the appropriate boxes, and staple the buyer card and seller card onto the report as indicated.

Before releasing the pair, ensure that the trade was a legal transaction and circle "yes" or "no" accordingly on the transaction report form. The agreed upon price should be equal to or somewhere between the buyer and seller prices. If both the buyer and seller prices are above or below the agreed upon price, then there is something wrong with the trade. Determine who has made the error and explain to that player that his profit for the round will be zero. Inform the other trading partner that while he did not make an error, the maximum profit he can receive is the difference between the buyer and seller cards. Inform him of this amount so that he can update his feedback form accordingly. On the report form, record the appropriate amended price. 
In each round it is likely that for whatever reason, at least two people will fail to trade. When players fail to trade in any round, complete the "Trade Failure Report." List all buyers and sellers who were unable to reach an agreement during the round and staple their cards at the bottom of the page. The order you record the buyers and sellers does not matter; you do not need to keep track of which players attempted to trade with each other.

At the end of every round, ensure that all 20 players have been recorded either on a transaction report or the trade failure report. If you do not count 20 cards stapled to the report forms, do not continue with the game until all cards are accounted for. Ensure all reports from the round are inserted together in the record collection envelope.

\section{After Round 1:}

As I mentioned, we would like you to answer just a few follow up questions after each round. The first question is: "Were you satisfied with the price you agreed upon in that last round?" If you are satisfied, it means you feel you are happy with the outcome of the negotiation and the profit you earned. Please circle "Yes" or "No" in the space on your answer sheet. If you did not trade, please circle "DNT" signifying "Did not Trade."

Second, how many different buyers/sellers did you talk to during round before you made the agreement? If you did not trade, how many people did you attempt to trade with before you decided not to make a deal? Do not count any fellow buyers/sellers you spoke with and only count each person one time. This means that if you spoke with three people and then went back to finalize a trade with the first person you talked to, you would still only record having spoken with three people.

Does anyone have any questions now?

[Answer any remaining questions.]

Then let's continue to play the remaining rounds of the game.

[Game proceeds for 10 rounds. Ask the same two questions listed above after each round.] 